\title{
The Method of Calculating the Settlement of Weak Ground Strengthened with the Reinforced Sandy Piles
}

\author{
Tatyana Maltseva ${ }^{1, *}$, Aleksandr Nabokov ${ }^{1}$, Yuri Novikov ${ }^{1}$, and Vladimir Sokolov ${ }^{1}$ \\ ${ }^{1}$ Industrial University of Tyumen, 625001, Volodarskogo str., 38, Tyumen, Russia
}

\begin{abstract}
The paper presents an engineering method for calculating the weak clay base, strengthened with sandy piles reinforced along the contour. The method is based on the principle of layer-by-layer summation, which is used when designing the bases and foundations. The novelty of the suggested method lies in the taking account of the soil reaction along the pile lateral surface and the impact of external vertical loads on the vertical displacement of the base.
\end{abstract}

\section{Introduction}

With the advent of geosynthetic materials used as reinforcing elements, it is getting popular to use one of the ways of strengthening the weak clay base with sandy piles reinforced along the contour [1-13]. Problems with weak clay bases are sufficiently presented in [14, $15]$.

The lack of a unified algorithm for calculating stress and strain states of the base strengthened with sandy piles reinforced along the contour, makes it difficult to extensively use these piles in a low-rise construction $[1,13]$.

Along with the capacity to predict base settlement by using software package, the practical value can also be seen in engineering-analytical method of calculating the strain state of the reinforced base $[11,12]$.

The article proposes method of calculation based on the Boussinesq solution in terms of the model of deformable solids. Therefore, the parameter of interstitial water viscosity is not considered explicitly. Deformation modulus is determined by experiment with watersaturated sample, which does not reflect the influence of pore water clearly. The time factor does not appear in the proposed method because his influence on the settlement of the soft clay soils is described in detail earlier by T. Maltseva and A. Minaeva $[1,13,17]$.

\section{Review}

\footnotetext{
Corresponding author: tgasu.maltseva.tatyana@mail.ru
} 
A technique for strengthening the bearing capacity and stability of the foundations built on weak water-saturated soils was patented [4]. According to this technique, a sandy pile reinforced vertically along the contour with a geosynthetic permeable element (geogrid) is arranged under the shallow foundation in the ground bed composed of weak soil [5].

The researches [6,7 and 8] are describing the laboratory experiments, which shows us efficiency of application of reinforced sandy piles. The detailed information [1] is presenting visually in Fig. 1.

The figure shows that the reinforced sandy pile has 55\% less settlement compared to natural ground bed and 30\% less settlement compared to non-reinforced sandy pile $[5,7]$.

Full-scale experiments $[8,9]$ have revealed, that load, which is obtained from the lowrise building is $\mathrm{P}=0.111 \mathrm{MPa}$. On this basis, appropriate settlement of low-rise building is $\mathrm{S}=0.0252 \mathrm{~m}$.

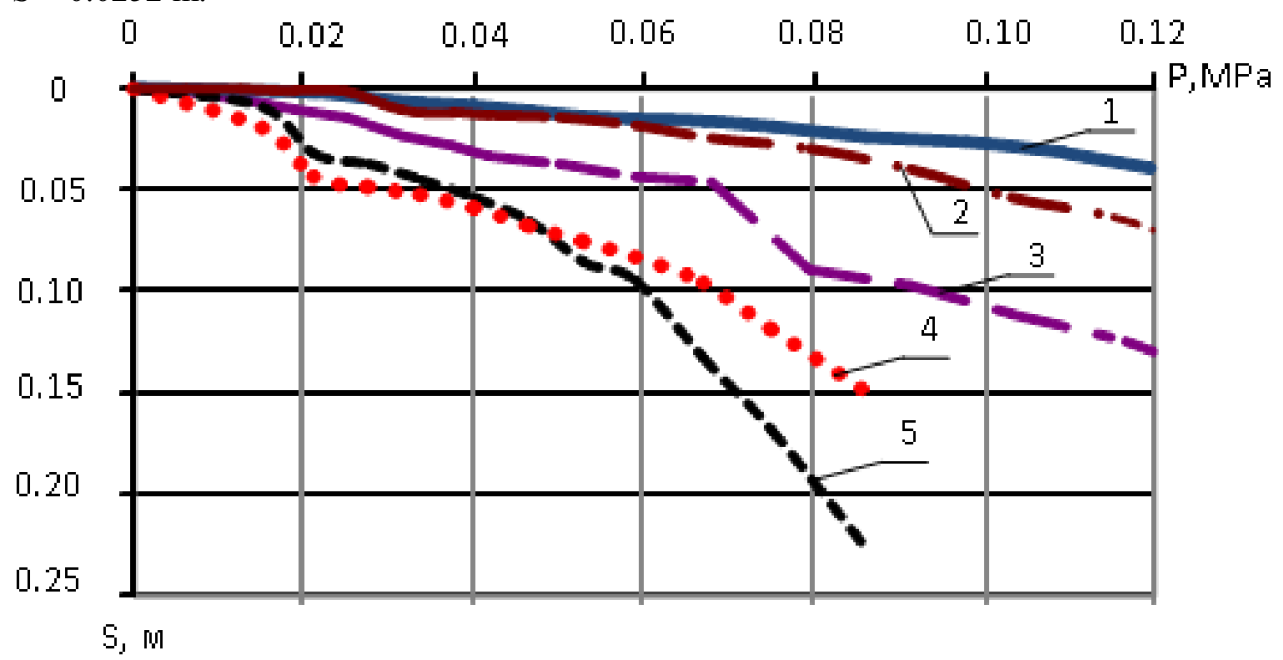

Fig. 1. "Settlement-pressure" diagrams:

1 - foundation soil reinforced with a sandy pile; 2 - foundation soil with a driven sandy pile; 3 foundation soil reinforced vertically with a geogrid along the contour; 4 - foundation soil reinforced vertically with a permeable element (a film) along the contour; 5 - unstable foundation soil.

\section{Problem}

Let us analyze a homogeneous cylinder of sand placed in a closed shell (reinforcing element - geogrid), beyond which lies an elastic isotropic material - clay soil (Fig. 2). We replace the effect of clay soil on the cylinder walls with the force of friction Ff. The cylinder is being affected with the static distributed load q. The calculation of sandy cylinder settlement (induced by the external forces) is basing on the principle of layer-bylayer summation, according to which the settlement is defined as a sum of settlements of elementary soil layers. Let us split the reinforced sandy cylinder with height $\Delta \mathrm{z}[\mathrm{m}]$ and the cross-sectional area A [m2] into elementary parts (Figure 3). 


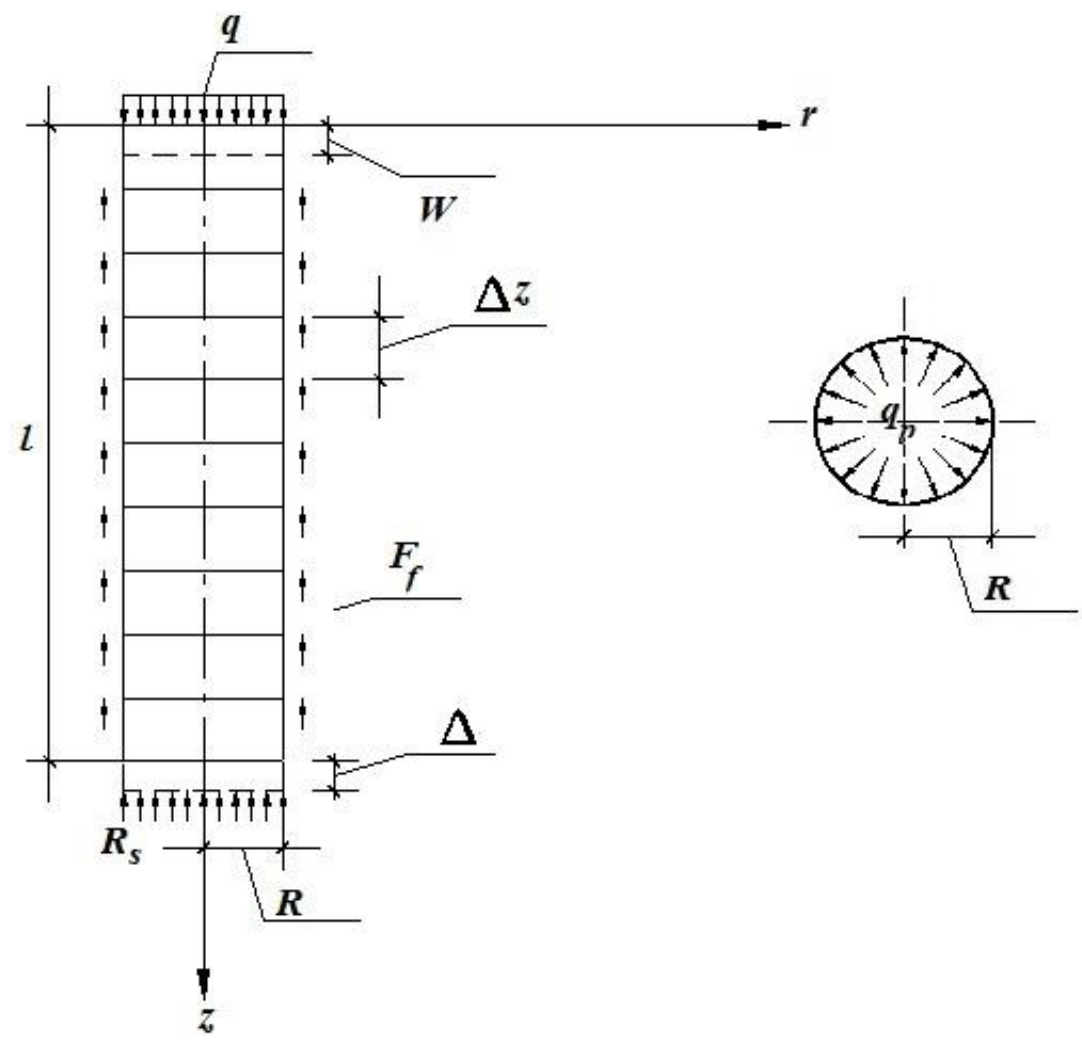

Fig. 2. Structural design

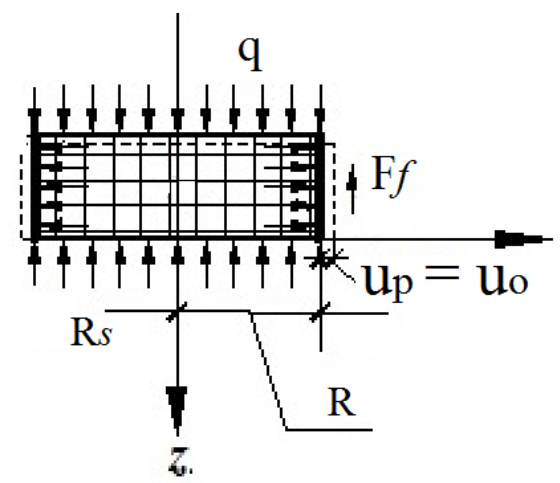

Fig 3. Elementary layer of the sandy pile reinforced along the contour

\section{Description of studies}

External loads cause the settlement of the sandy pile reinforced along the contour. This settlement is a combination of two components: the settlement of a pile shaft $\Delta \mathrm{w}$ and shift of pile foot $\Delta$.

$$
W=\sum \Delta w_{i}+\Delta
$$


where $\Delta$ is also set or determined by layer-by-layer summation method in accordance with construction regulations.

Let us present the settlement of a reinforced sandy pile shaft as a sum of settlements of elementary soil layers $\sum \Delta w_{i}$, which pile had previously been divided into.

We determine the settlement of the elementary layer of the sandy pile reinforced along the contour as the sum of

vertical displacement of pile shaft (sand) under the impact of the external load - $\Delta w_{q}$,

vertical displacement under the impact (reaction) of the reinforcing element $-\Delta w_{q p}$,

vertical displacements under the impact (reaction) of soil bearing pressure along the lateral area $-\Delta w_{q s}$ :

$$
\Delta w=\Delta w_{q}+\Delta w_{q p}+\Delta w_{q s},
$$

The paper [2] presents the calculation of settlement excluding forces of friction generated along the outer lateral surface of the cylinder.

To determine the vertical displacements of the filler $\Delta \mathrm{wq}$ caused by the external load $\mathrm{q}$, we formulate the equilibrium equation of the object:

$$
\mathrm{N}-\mathrm{Ff}=0,
$$

where $\mathrm{N}$ is the stress that occurs in shaft of a sandy pile reinforced along the contour. This stress is caused by the external load $\mathrm{q}$ and the reaction soil bearing pressure Rs [kPa]; $\mathrm{Ff}$ is the force of friction along the lateral surface $[\mathrm{kN}]$.

Stress $\mathrm{N}$ is

$$
\mathrm{N}=\mathrm{q} \cdot \mathrm{A}-\mathrm{Rs} \cdot \mathrm{A}
$$

According to Hooke's law, the reaction Rs will be presented in the form of equation:

$$
R_{s}=E_{r} \cdot \frac{\Delta w_{q}}{\Delta z},
$$

where $\mathrm{Er}$ is a reduced modulus of the filler (sand) deformation $[\mathrm{kPa}] ; \Delta \mathrm{wq}$ is an absolute deformation of the elementary layer of finite length [m].

The frictional force of the elementary layer along the lateral surface is proportional to the displacement $\Delta z$ :

$$
F_{f}=k \cdot \Delta z=u \cdot f_{i} \cdot \Delta z
$$

where $\mathrm{k}$ is the coefficient of friction $[\mathrm{kN} / \mathrm{m}]$; $\mathrm{u}$ is the external perimeter of a pile crosssection $[\mathrm{m}] ; f_{i}$ - the calculation resistance of the i-th layer of soil along the lateral surface of the base $[\mathrm{kPa}]$ is determined from the equation [16]:

$$
f_{i}=2 \cdot \pi \cdot r_{i} \cdot c_{i} \cdot \operatorname{tg} \varphi_{i}
$$

where ri - radius [m]; ci - the adhesion $[\mathrm{kPa}] ;$ i - angle of internal friction.

Plugging equations (4), (5) and (6) in the equation (3), and expressing $\Delta$ wq, we obtain the absolute deformation of the elementary $i$ layer: 


$$
\Delta w_{q i}=\frac{q \cdot A \cdot \Delta z_{i}}{E_{r} \cdot A+u \cdot \Delta z_{i} \cdot f_{i}}
$$

The vertical displacements of the pile shaft with account for impact (reaction) of the reinforcing element $\Delta w q p$ are defined by the equation:

$$
\Delta w_{q p i}=-\frac{v \cdot q_{p_{i}} \cdot \Delta z_{i}}{E_{r}}
$$

where $v$ is the Poisson's ratio; qpi is a reaction of reinforcing element in the elementary layer of finite length $[\mathrm{kN} / \mathrm{m} 2]$.

Reaction of the reinforcing element qp with account for soil bearing pressure along the lateral area of the pile is determined from the condition of equality of the radial movements of reinforcing element and sand $\mathrm{u} 0=\mathrm{up}[13]$ :

$$
q_{p}=\frac{v \cdot q_{z i}}{\frac{E_{r} \cdot R}{C_{p} \cdot \delta}+1-v},
$$

where $\mathrm{R}$ is a radius of a sandy pile reinforced along the contour $[\mathrm{m}] ; \delta$ - thickness of the reinforcing element $[\mathrm{m}] ; \mathrm{Cp}$ is the equivalent of elasticity modulus of the reinforcing element $[\mathrm{kN} / \mathrm{m} 2]$; qzi - magnitude of the vertical stresses having impact on the elementary layer $[\mathrm{kN} / \mathrm{m} 2]$.

Reinforcing element modulus of elasticity is determined in [5]:

$$
C_{p}=\frac{E_{r} \cdot R \cdot\left(K_{a}^{e x}-1\right)}{\delta \cdot\left[v^{2} \cdot K_{a}^{e x}-\left(K_{a}^{e x}-1\right) \cdot(1-v)\right]}
$$

where $K_{a}^{e x}$ is a magnification coefficient of deformation module of the reinforced elementary layer.

Vertical intensity height along the sandy pile reinforced along the outline is approximated to a tolerance of $10 \%$ in accordance with the experimental information and is determined in a quadratic dependence [17]:

$$
q_{z}=0,20445714-0,042892854 \cdot z+0,003794642 \cdot z^{2} .
$$

Vertical displacements $\Delta$ wqs of the pile shaft from the effects of for soil bearing pressure qsi along the lateral area are determined by:

$$
\Delta w_{q s}=-\frac{v \cdot q_{s_{i}} \cdot \Delta z_{i}}{E_{r}}
$$

Soil surrounding the pile is to be considered as a linearly elastic environment with a coefficient of soil resistance $\mathrm{Cz}[\mathrm{kN} / \mathrm{m} 3]$ :

$$
q_{s}=C_{z} u_{s}, \quad C_{z}=\frac{K \cdot z}{\gamma_{c}},
$$

where $\mathrm{K}$ is a constant of proportionality $[\mathrm{kN} / \mathrm{m} 4]$, which is dependent on the type of soil surrounding the pile; $\mathrm{z}$ is the depth of the pile section in the ground $[\mathrm{m}] ; \gamma \mathrm{c}$ - coefficient of service factor. Basing on the condition that the radial displacements of the reinforcing element are equal to the radial displacements of the surrounding soil $u_{o}=u_{s}$, the reaction 
of soil bearing pressure on the lateral surface of the elementary layer qs is determined from the equation:

$$
q_{s}=\frac{q_{p} \cdot R^{2} \cdot C_{z}}{C_{p} \cdot \delta}
$$

\section{Conclusion}

Results of the analytical and numerical simulation (which were made by FEM model and PLAXIS software) of reinforced base were compared.

Soils with physical and mechanical characteristics similar to soils of on-site field research were taken for calculation by elastic-plastic model with the Mohr-Coulomb strength criterion.

Figure 4 presents "settlement-pressure" diagrams, plotted basing on experimental data calculated by the proposed method and data of numerical simulation.

The diagrams show that the difference between the final settlements of the base (strengthened with the sandy pile reinforced along the outline) calculated by the proposed method and the data of in-situ tests is $22 \%$, the calculation data in "PLAXIS 3D" software package $-37 \%$, the calculation data in "FEM models" program complex - $19 \%$.

The proposed engineering method of calculation allows to significantly increase the effectiveness in projecting the reinforced soil foundations and thus allows to extend the sphere of application of this method for strengthening the weak clay ground.

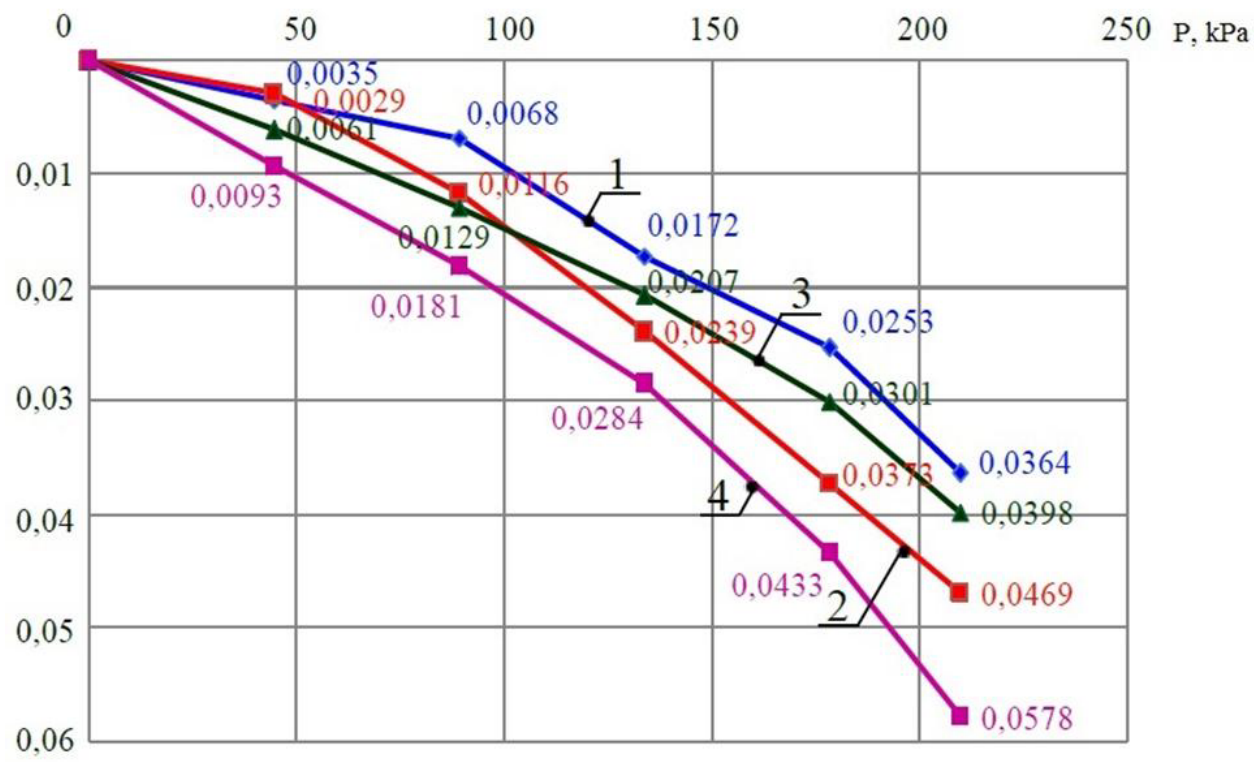

$\mathrm{S}, \mathrm{m}$

Fig. 4. Comparison of the settlements calculation results:

1 - experimental data; 2 - theoretical calculation according to the method; 3 - the results of numerical simulation in "FEM models" software package; 4 - results of numerical simulation in "PLAXIS 3D" software package. 


\section{References}

1. T. Maltseva, A. Nabokov, A. Chernykh. Procedia Engineering, 117, 239-245 (2015)

2. S. Sannikov, Avtoref. dis. na soisk. uch. step. kand. tekh. Nauk, Tyumenskaya gosudarstvennaya arkhitekturno-stroitelnaya akademiya, (2004)

3. A. Kraev, Vestnik Tomskogo arkhitekturno-stroitelnogo universiteta, 4, 146-151 (2008)

4. Pat. 2361979, MPK51 E 02 D 27/08. Sposob povysheniya nesushhej sposobnosti i ustojchivosti fundamentov na slabyh vodonasyshhennyh gruntah (2009) - Bjul. №20.

5. A. Kraev, Dissertacija na soiskanie uchenoj stepeni kandidata tehnicheskih nauk, Tjumenskaja gosudarstvennaja arhitekturno-stroitel'naja akademija, (2009)

6. V. Baj, A. Nabokov, V. Voroncov, A. Kraev, Vestnik grazhdanskih inzhenerov, 2, 74 76 (2009)

7. A. Kraev, Nauchno-tehnicheski vestnik Povolzhya, 5, 221-224 (2013)

8. A. Nabokov, Dissertacija na soiskanie uchenoj stepeni kandidata tehnicheskih nauk (2003)

9. Ju. Novikov, Nauchno-tehnicheskij vestnik Povolzh'ja, 6, 225-229 (2011)

10. V. Baj, A. Kraev, A. Nabokov, Ju. Novikov, Nauchno-tehnicheski vestnik Povolzh'ja, 2, 30-33 (2011)

11. V. Baj, T. Maltseva, A. Kraev, Nauchno-tehnicheskij vestnik Povolzh'ja, 5, 108-111 (2014)

12. V. Baj, A, Kraev, Vestnik grazhdanskih inzhenerov, 3, 107-110 (2014)

13. L. Maltsev, T. Maltseva, A. Minaeva, A. Nabokov, Nauchno-tehnicheskij vestnik Povolzh'ja, 2, 234-238 (2012)

14. T. Maltseva, Matematicheskaja teorija vodonasyshhennogo grunta (Izdatel'stvo «Vektor Buk», Tjumen', 2012)

15. V. Baj, L. Maltsev, T. Maltseva, A. Nabokov, V. Demin, Jeksperimental'naja ustanovka dlja ispytanija grunta metodom odnoosnogo szhatija (2002): Patent na izobretenie RUS 2213952

16. K. Shadunts, Izd-vo FGOU VPO KubGAU politematicheski setevoi elektronny nauchni zhurnal Kubanskogo gosudarstvennogo agrarnogo unversiteta (2006)

17. V. Baj, T. Maltseva, A. Nabokov, V. Voroncov, A. Minaeva, Izvestija vysshih uchebnyh zavedenij. Neft' i gaz, 1, 102-106 (2011)

18. Ju. Novikov, Issledovanie raboty pesceanih armirovannih po konturu svai v slabih glinistih osnovanieah pod lentochnimi fundamentami, $\mathrm{PhD}$ Thesis (2015) 